\title{
Article
}

Mycosphere

Doi 10.5943/mycosphere/7/5/4

Copyright $($ ) Guizhou Academy of Agricultural Sciences

\section{Mycosphere Essays 12. Progress in the classification of the water- cooling tower ascomycete Savoryella and a tribute to John Savory: a review}

\author{
Jones EBG ${ }^{1 *}$, To-anun $C^{1}$, Suetrong $S^{2}$ and Boonyuen $\mathbf{N}^{2}$ \\ 'Department of Entomology and Plant Pathology, Faculty of Agriculture, Chiang Mai University \\ Chiang Mai Province, Thailand 50200 \\ ${ }^{2}$ BIOTEC, National Science and Technology Development Agency (NSTDA), 113 Thailand Science Park, Thanon \\ Phahonyothin, Tambon Khlong Nueng, Amphoe Khlong Luang, Pathum Thani 12120, Thailand
}

Jones EBG, To-anun C, Suetrong S, Boonyuen N 2016 - Mycosphere Essays 12. Progress in the classification of the water-cooling tower ascomycete Savoryella and a tribute to John Savory: a review. Mycosphere 7(5), 570-581, Doi 10.5943/mycosphere/7/5/4

\begin{abstract}
The genus Savoryella belongs in the family Savoryellaceae (Savoryellales, Hypocreomycetidae, Sordariomycetes) and its species have a worldwide distribution. A natural classification was not possible when the genus was introduced, since it predated molecular phylogenetic studies; therefore morphology-based descriptions only were provided. In this review we discuss the history and significance of the genus, illustrate its morphology and discuss its role in the colonization and biodeterioration of lignocellulosic materials. Molecular analyses of SSU, LSU and RPB2 sequence data placed the genus in the Hypocreomycetidae with high support and resulted in the introduction of the order Savoryellales. The role of Savoryella in the soft rot decay of wood is also discussed.
\end{abstract}

Key words - Phylogeny - Savoryellaceae - taxonomy - water cooling towers - wood decay

\section{Introduction}

The senior author first came across Savoryella (an unidentified member of the Ascomycota) as an undergraduate student in 1957 on a vacation placement at the Princes Risborough Research Laboratory, near Aylesbury, Bucks., UK. The senior author was assigned to John Savory to learn aspects of soft rot of timber in water cooling towers and came across a number of unidentified fungi. My undergraduate project was on soft rot decay of marine fungi, a little known group at that time.

During 1960-1962, I was commissioned to examine timber from water cooling towers with circulating brackish water and documented fungi on both treated and untreated wood (Jones 1962, unpublished data). Timbers in these towers showed extensive decay, premature failure of the wood preservative treatment and it was necessary to identify the causative organisms. Many of these were marine fungi, but others could not be identified; however, time did not allow a more detailed study as I was studying for my Ph.D. on the physiology of marine fungi. 


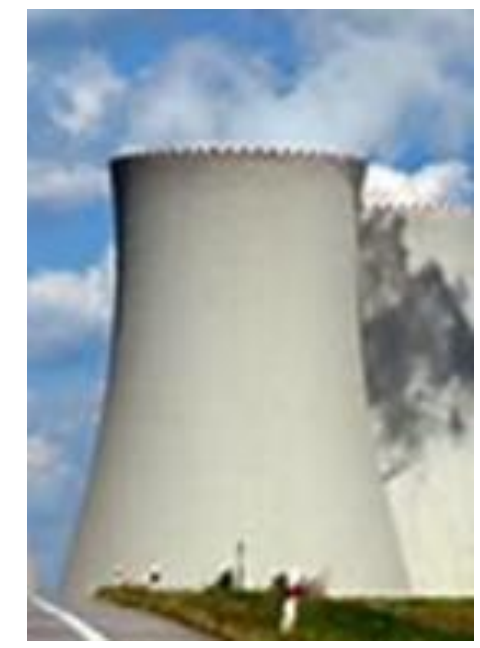

Fig. 1 - Typical water cooling tower.

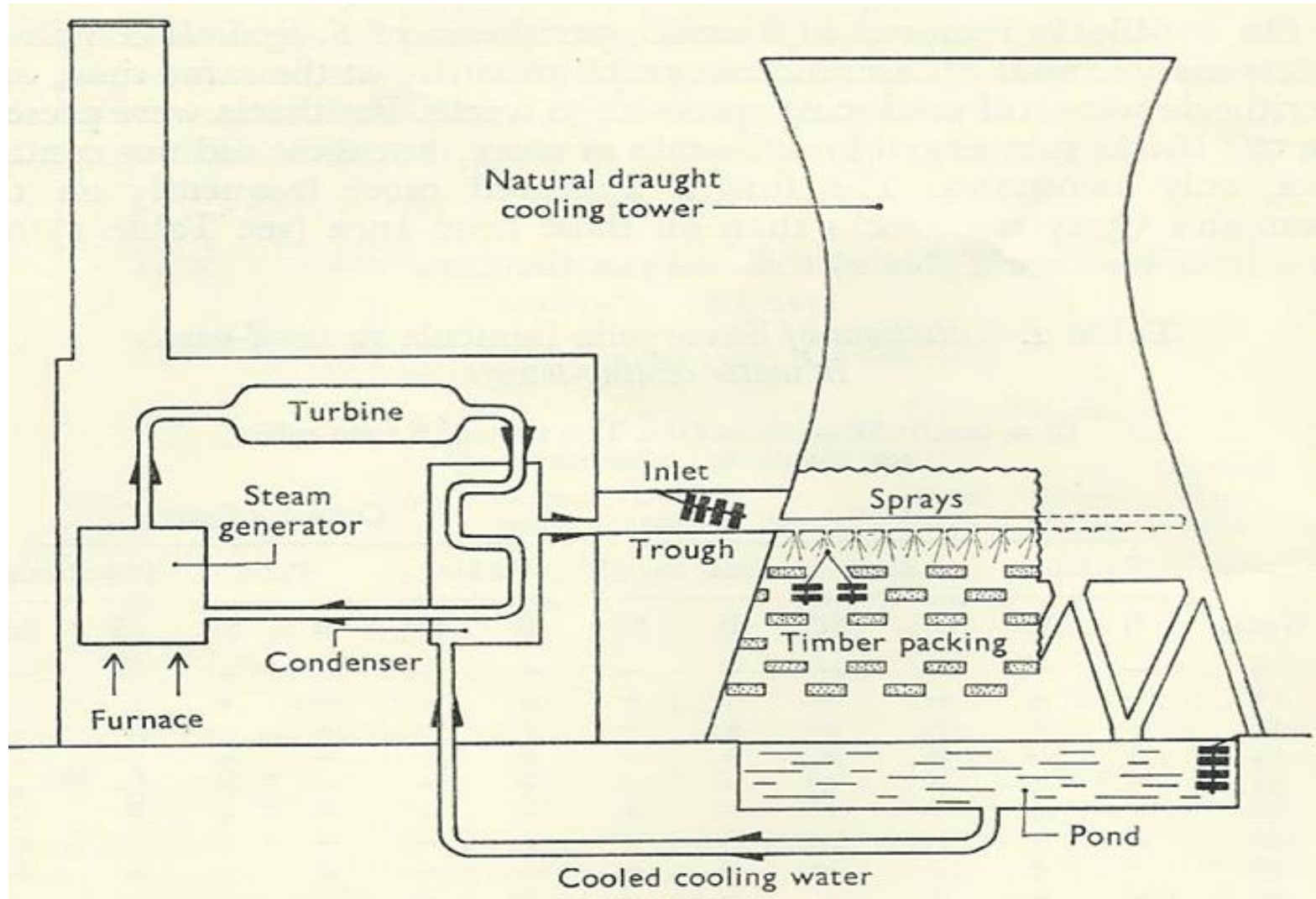

Fig. 2 - Diagram of water cooling tower indicating sampling positions in the inlet trough, timber packing and pond.

Clearly, timber in water cooling towers supported a rich and unique micro fungal community, which had not been investigated in any detail (Baechler \& Richards 1961, Baker 1950, 1951, 1954, Findlay \& Savory 1950). Thus, on completion of my Ph.D., I started as a lecturer at the Portsmouth Regional Technical College and in due course took on my first postgraduate students. Rod Eaton was one of my first postgraduate students and was set the task of documenting the ecology and taxonomy of the fungi colonizing timber in water cooling towers.

A comprehensive study was undertaken to document the fungi on treated and untreated timber from a wide range of cooling towers spread across the UK, the exposure of treated and untreated wood test blocks at selected towers, determine the wood decay ability of isolated fungi 
and a chemical analysis of water used in the various cooling towers. Mechanical draught water cooling towers have a distinctive appearance (Fig. 1) and were attached to electric-generating power stations to cool down water circulating through the condensers.

The warm water was piped to the cooling tower and sprinkled over a stack of wooden slats and the water collected in ponds below the packing and recirculated to the condensers (Fig. 2). Air was drawn through the towers; thus cooling the water running through the wooden slats. Some 16 cooling towers, mainly in the north of England, were sampled for the micro fungi growing on their timbers (Eaton \& Jones 1971a, b, Eaton 1972).

A recurring species in the study was an ascomycete and after much debate, it was decided to introduce a new genus, namely Savoryella with $S$. lignicola as the type species (Jones \& Eaton 1969) (Fig. 3).

Title - Savoryella lignicola gen. et sp. nov., from water cooling towers. (1969) Transactions of the British Mycological Society 52: (1), 161-174.

\section{Savoryella gen.nov.}

Perithecia solitaria vel gregaria, substrato immersa vel partim immersa, pallido vel atro brunnea, collo brevi, periphysato. Asci unitunicati, cylindracei et aparaphysati. Ascospori octo, triseptati, loculis extremis hyalinis et loculis mediis brunneis. Species typica: S. lignicola Jones \& Eaton.

\section{Savoryella lignicola sp.nov. (P1. 9).}

Perithecia $200-345 \times 120-180 \mu \mathrm{m}$, collo $80-165 \times 72 \mu \mathrm{m}$, solitaria vel gregaria, substrato immersa vel partim immersa, pallido vel atro brunnea, membranacea et aparaphysata. Asci I 28- I 80 $\times$ I 6-24 $\mu \mathrm{m}$ unitunicata, longo-cylindracei. Ascospori octo, 24.5$33.5(43 \cdot 0) \times 8 \cdot 5^{-12} \cdot 5 \mu \mathrm{m}$, ellipsoidei, triseptati, loculis extremis hyalinis $(2 \cdot 6-6 \cdot 0 \mu \mathrm{m})$ et loculis mediis brunneis (10.6-16.0 $\mu \mathrm{m}$ ).

Perithecia $200-345 \times 120-180 \mu \mathrm{m}$, neck $80-165 \times 72 \mu \mathrm{m}$, solitary to aggregated, immersed or partly immersed in the substratum, globose, pale to dark brown in colour, membranous with well defined wall and aparaphysate. Asci I 28-180 $\times$ I6-24 $\mu \mathrm{m}$, long-cylindrical with a short foot, 8-spored and unitunicate. Ascospores 24.5-33.5 (43.0) $\times 8.5-12.5 \mu \mathrm{m}$, ellipsoidal, triseptate, central cells brown (10.6-16.0 $\mu \mathrm{m}$ ) and the end cells hyaline $(2 \cdot 6-6 \cdot 0 \mu \mathrm{m})$.

On Scots pine test-blocks placed for I 68 days (I6 June, I966- I December, I966) amongst the packing timber of a water-cooling tower at Connah's Quay, Flintshire, North Wales. Type: IMI I 29784.

\section{Phylogenetic placement of Savoryella lignicola}

At that time, the genus could not be assigned to any higher order taxon, and subsequently various authors attempted its classification, based on morphological features: Sphaeriales incertae sedis (Kohlmeyer \& Kohlmeyer 1979), Xylariales (Eriksson \& Hawksworth 1986), Halosphaeriales (Read et al. 1993), Sordariales (Jones \& Hyde 1992) and Hypocreales (Vijaykrishna et al. 2006). The current classification of the genus Savoryella is shown as follows:
Phylum:
ASCOMYCOTA
Class:
SORDARIOMYCETES
Subclass:
HYPOCREOMYCETIDAE
Order:
SAVORYELLALES
Family:
SAVORYELLACEAE
Genus:
SAVORYELLA
Type species: Savoryella lignicola EBG Jones \& RA Eaton 


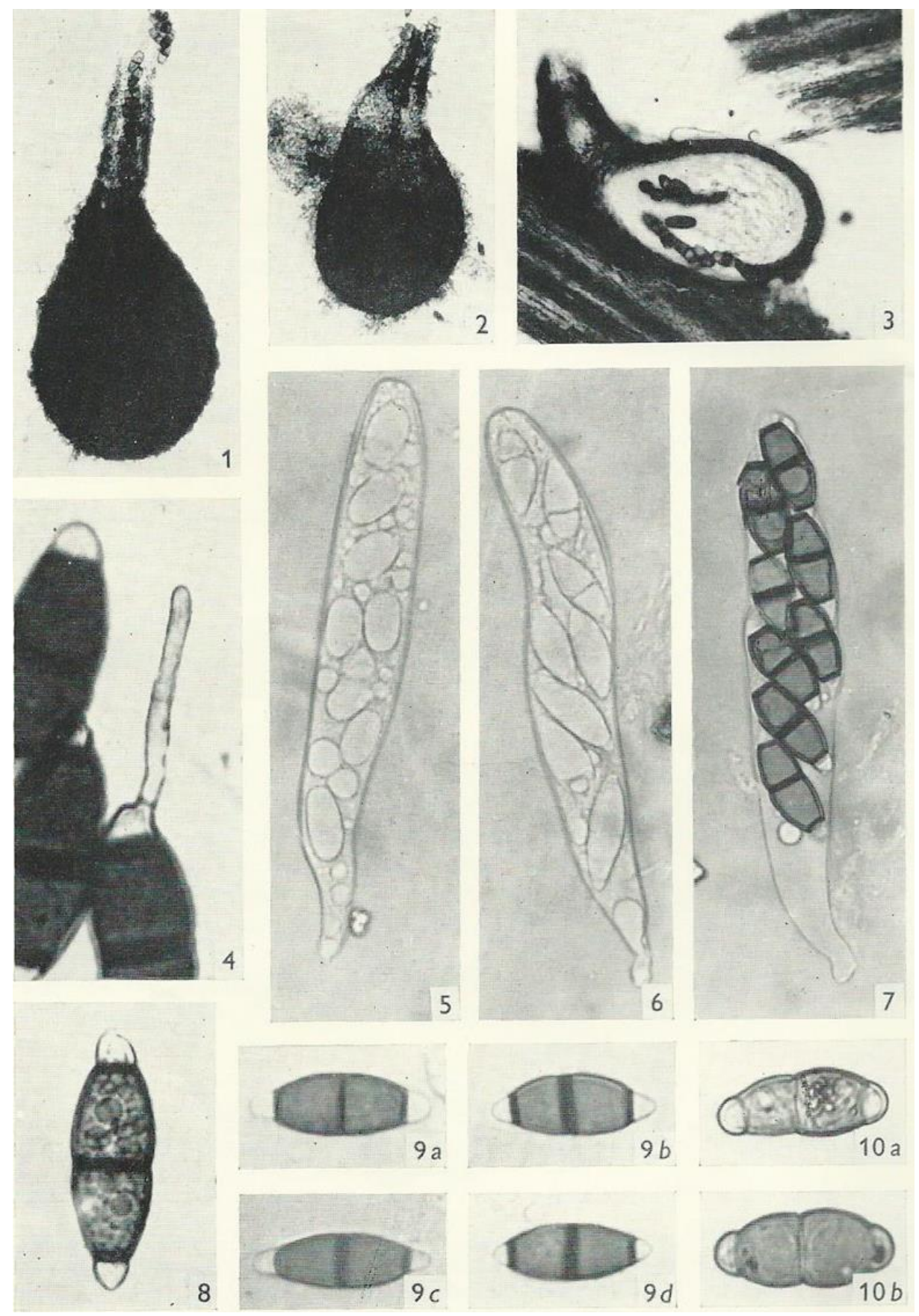

Fig. 3 - Original illustration of Savoryella lignicola, reproduced with permission of the British Mycological Society.

Currently, ten species are known and worldwide in their distribution:

1978: Savoryella verrucosa Minoura \& T. Muroi

1982: Savoryella paucispora (Cribb \& JW Cribb) J Koch

1992: Savoryella appendiculata KD Hyde \& EBG Jones

1992: Savoryella longispora EBG Jones \& KD Hyde

1993: Savoryella aquatica KD Hyde

1994: Savoryella grandispora KD Hyde

1997: Savoryella curvispora WH Ho, KD Hyde \& Hodgkiss

1997: Savoryella fusiformis WH Ho, KD Hyde \& Hodgkiss

1998: Savoryella limnetica HS Chang \& SY Hsieh (now referred to Ascotaiwania)

2000: Savoryella melanospora Abdel-Wahab \& EBG Jones 

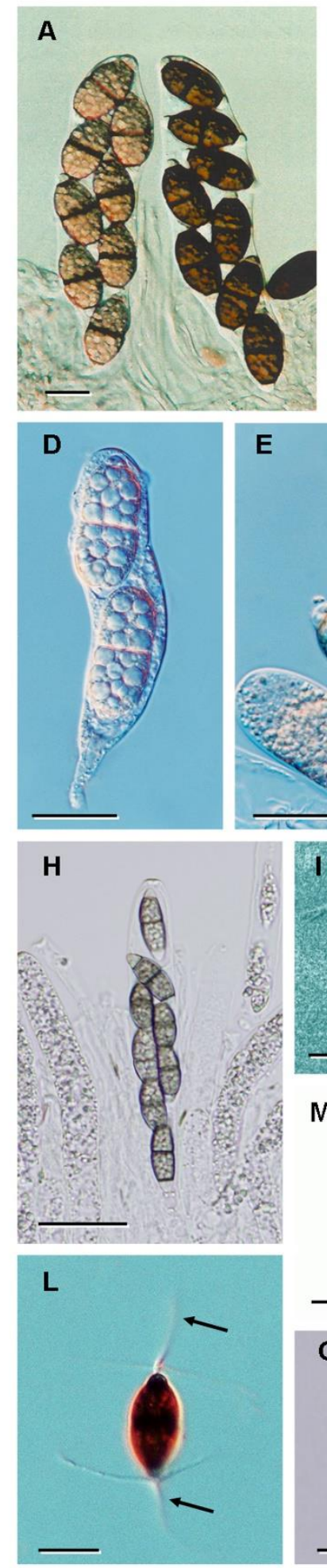
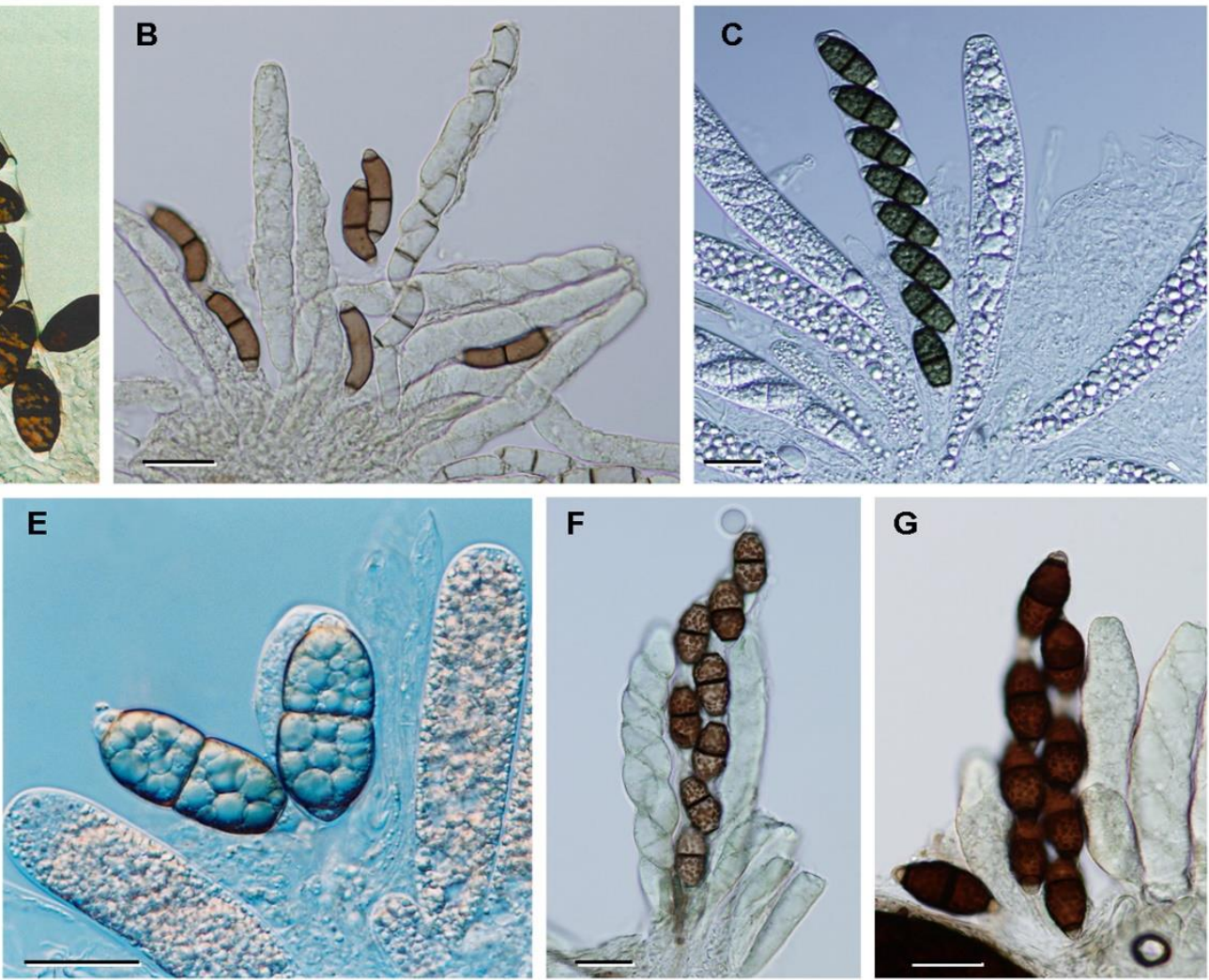

$\mathbf{F}$

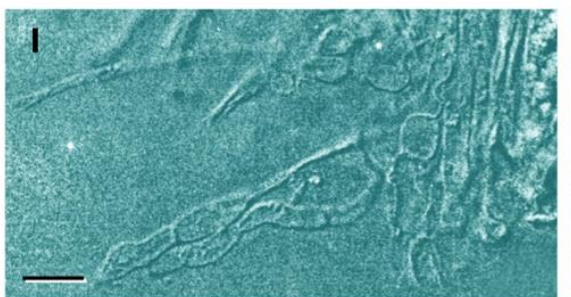

M
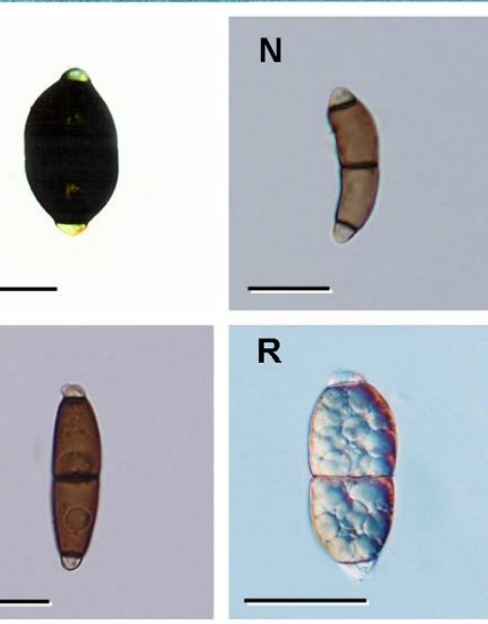
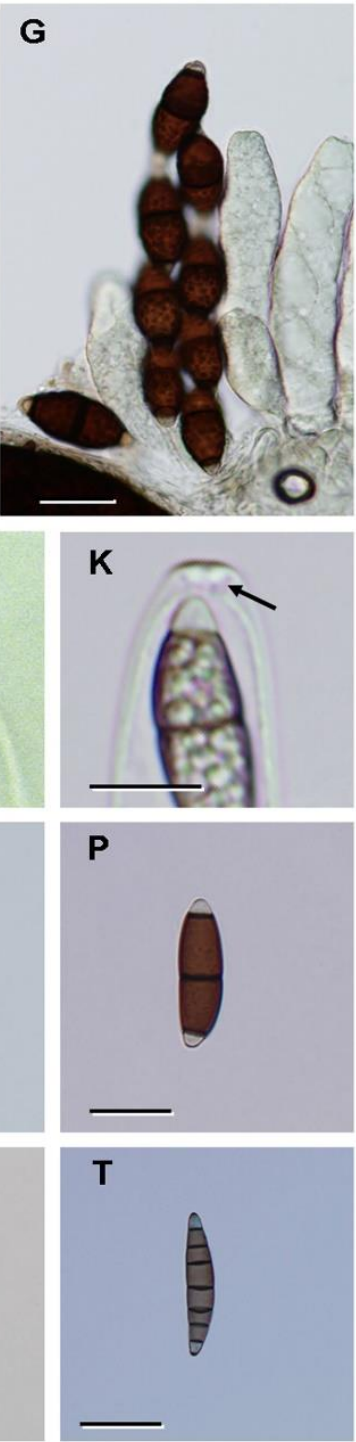

Fig. 4 - Savoryella and its related species from (Boonyuen et al. 2011 in Mycologia and Jones \& Hyde 1992 in Botanica Marina). A. Savoryella aquatica. B. S. curvispora. C. S. lignicola. D-E. S. paucispora. D. Young two spored ascus. E. Mature and immature asci and paraphyses. F-G. $S$. verrucosa. H. Ascothailandia grenadoidea. I. S. longispora. J. S. aquatica (apical ring, arrow). K. A. grenadoidia (apical ring, arrow). L. S. appendiculata (ascospore with appendages, arrow). M. S. aquatica. N. S. curvispora. O. S. fusiformis. P. S. lignicola. Q. S. longispora. R. S. paucispora. S. S. verrucosa. T. Ascotaiwania lignicola. Scale bars A-E, L-T $=20 \mu \mathrm{m}, \mathrm{F}-\mathrm{H}=25 \mu \mathrm{m}, \mathrm{I}-\mathrm{K}=10 \mu \mathrm{m}$. Reproduced from Mycologia with permission of the Mycological Society of America. 


\section{Other cooling tower fungi}

Some 58 and 29 microfungi were found growing on beech (Fagus sylvatica L.) and Scots pine (Pinus sylvestris L.) test blocks, respectively, at the 16 water cooling towers sampled over a three-year period, but only a few could be fully identified (Eaton 1972). This was a new environment to be sampled for fungi and a number of new taxa were described: Delitschia bispora RA Eaton \& EBG Jones, Phaeonectriella lignicola RA Eaton \& EBG Jones, Taeniolella longissima RA Eaton \& EBG Jones, Phaeonectriella lignicola RA Eaton \& EBG Jones, and Tricladium varium EBG Jones \& RJ Stewart (Eaton \& Jones 1970, Jones et al. 2002, Jones \& Stewart 1972).

Many others remain to be recollected and described, as this is a unique habitat for fungi. The most common fungus reported was Monodictys putredinis (Wallr.) S Hughes, present at all sites and at each sampling period over the three years. Chaetomium globosum Kunze ex Fr., Graphium spp. and Doratomyces microsporus (Sacc.) FJ Morton \& G Sm., were also common, but at fewer test sites. The only other studies that documented fungi in water cooling towers are those of Natarajan and Udaiyan (1978), and Udaiyan and Manian (1991a, b) who replicated the studies carried out in the UK. This study was probably instigated by CV Subramanian who visited Portsmouth to learn more about marine fungi. They listed 103 species (4 Zygomycota, 26 Ascomycota, 3 Basidiomycota and 73 asexual morphs) on beech and Scots pine test blocks exposed at a water cooling tower in Madras, India. Only eight species were common to both studies, including the new species $S$. lignicola and Ph. lignicola.

In both the UK and Indian studies, beech test blocks supported a greater diversity of species when compared to Scots pine and this has been reported in other studies (Byrne \& Jones 1974). In total, some 150 fungi have now been recorded from this unique habitat; however, few of these large water cooling towers remain in the UK as the old electric-generating power stations are decommissioned and pulled down.

\section{The genus Savoryella}

Currently, ten Savoryella species have been described as listed above. Boonyuen et al. (2011), in a combined phylogenetic analysis (LSU, SSU, 5.8S rRNA genes, rpb1, rpb2, and tef1 genes) of Savoryella species, showed that they formed a monophyletic group in the Sordariomycetes, but showed no affinities with accepted orders. All are reported from submerged wood in aquatic habitats: six from freshwater, four from marine or brackish water (including water cooling towers), while $S$. melanospora is known on driftwood from coastal sand dunes in Australia (Abdel-Wahab \& Jones 2000, Jones et al. 2015).

Savoryella melanospora has recently been collected on intertidal mangrove wood, in Colva, India by Borse et al. (2016). Although Savoryella species are worldwide in their distribution, most records are from the tropics/subtropics. All possess ellipsoidal, 3-septate ascospores, central cells brown, end cells hyaline, with or without polar appendages (Fig. 4). Savoryella appendiculata is the only species with bipolar tetraradiate appendages that are formed on release from the ascomata. Read et al. (1993) demonstrated at the ultrastructural level, that the appendages are formed as an outgrowth of the hyaline apical cell of the ascospore. This species is generally found growing on wood associated with sand, and may aid in the dispersal of ascospores.

\section{The order Savoryellales}

Boonyuen et al. (2011) showed that Savoryella species formed a unique clade in Hypocreomycetidae, Sordariomycetes, along with the genera Ascotaiwania, Ascothailandia and Canalisporium. With the one fungus-one name ruling (Hawksworth 2011, Taylor 2011), the genus Canalisporium had priority and thus Ascothailandia was synonymized under that name (Nawawi \& Kuthubutheen 1989, Sri-indrasutdhi et al. 2010, Réblová et al. 2016a, b). The Savoryellales clade forms a sister clade to the orders Coronophorales and Melanosporales, with strong statistical support. 


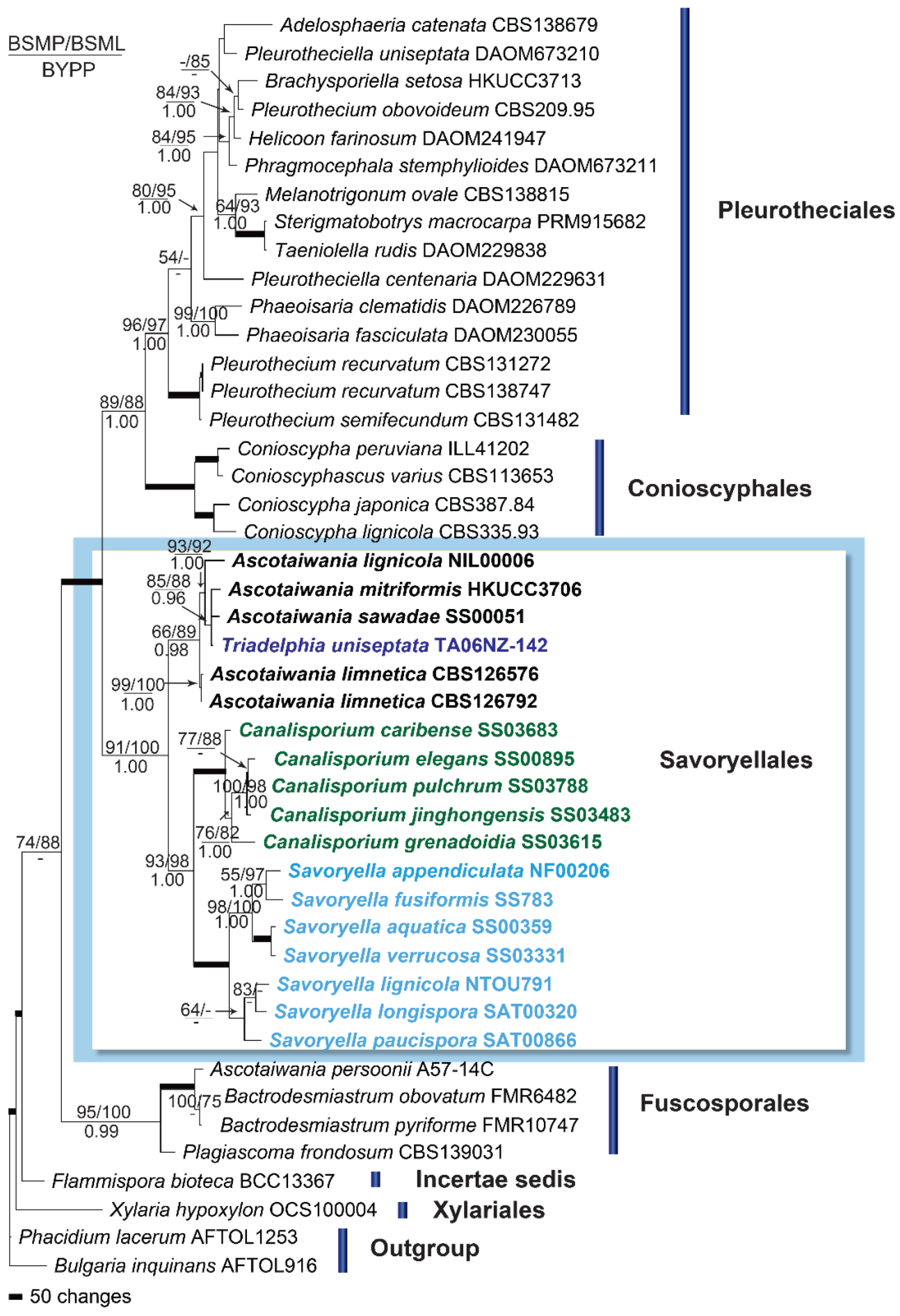

Fig. 5 - A single maximum parsimony tree inferred from combined SSU, LSU rDNA and rpb2 sequence data generated with maximum parsimony analysis. Maximum parsimony (BSMP, left) and likelihood (BSML, right) bootstrap values greater than $50 \%$ are given above the node. Bayesian posterior probabilities greater than 0.95 are given below each node (BYPP). The internodes that are highly supported by all bootstrap proportions (100\%) and posterior probabilities (1.00) are shown as a thicker line.

Ascotaiwania was shown to be polyphyletic with two species grouping with the type species A. lignicola Sivan. \& H.S. Chang, while Ascotaiwania hughesii Fallah, J.L. Crane \& Shearer did not group within the Savoryellales, but formed a separate clade in the Hypocreomycetidae (Boonyuen et al. 2011). Likewise, Ascotaiwania persoonii Fallah, J.L. Crane \& Shearer, has also been shown to group distant to the Savoryellales (Réblová \& Seifert 2004). Réblová et al. (2012) 
noted that Helicoön farinosum Linder (asexual morph of Ascotaiwania hughesii) grouped in the Helicoön sensu lato clade. Maharachchikubura et al. (2015), with wider sampling of other genera, included Carpoligna pleurothecii F.A. Fernández \& Huhndorf, Conioscyphascus varius Réblová \& Seifert, Conioscypha japonica Udagawa \& Toyaz. and Pleurothecium semifecundum Réblová, Seifert \& J. Fourn. in the Savoryellales clade. However, in the text Carpoligna, Conioscypha, Flammispora and Sterigmatobotrys were referred to as Savoryellales incertae sedis (Maharachchikubura et al. 2015), while Zelski et al. (2015) placed Conioscypha and Conioscyphascus species as a sister clade to the Savoryellales (Hypocreomycetidae incertae sedis). A more recent classification of the Hypocreomycetidae is published by Maharachchikubura et al. (2016).

Réblová et al. (2016a) have shown that Triadelphia uniseptata (Berk. \& Broome) P.M. Kirk nested within the monophyletic Ascotaiwania clade as a sister to A. mitriformis Ranghoo \& K.D. Hyde while Ascotaiwania persoonii nested in the Bactrodesmiastrum clade with high support, while Helicoön farinosum nested in the Pleurotheciales. More recently, Yang et al. (unpublished data) propose a new order Fuscosporales that accommodates the Bactrodesmiastrum clade, including Ascotaiwania persoonii and a number of new dematiaceous hyphomycetes.

Currently, Conioscypha and Pleurothecium have been referred to the new orders Conioscyphales and Pleurotheciales, respectively as shown in Fig. 5 (Réblová et al. 2016a, b). Many Ascotaiwania and Triadelphia species have not been sequenced and further alignments can be expected with the discovery of new genera and sequencing of other taxa.

\section{The family Savoryellaceae}

Jaklitsch and Réblová (2015) introduced this family to accommodate Savoryella species, unaware that Boonyuen et al. (2011) had introduced the order Savoryellales. Taxa currently assigned to the family based on Index Fungorum (2016), MycoBank (Crous et al. 2004), Faces of Fungi database (Jayasiri et al. 2015) and NCBI (http://www.ncbi.nlm.nih.gov/nuccore) are listed in Table 1.

\section{Soft rot decay of wood}

Many Savoryella species have been shown to cause soft rot decay of wood (Eaton \& Jones 1971a, b, Leightly \& Eaton 1977, Mouzouras 1986, Leightly 1980). This type of decay is prevalent where wood is exposed to wet conditions, such as submerged wood in marine and freshwater habitats (Jones 1972, Bucher et al. 2004a), water cooling towers (Findlay \& Savory 1950, Savory 1954a, b), archeological timbers (Jones \& Jones 1993), and terrestrial environments (Duncan 1960).

The term 'soft rot' was coined by Savory $(1954 \mathrm{a}, \mathrm{b})$ for fungi that caused decay of the secondary wood cell wall layers. This was described in timbers from water cooling tower packing and characterized by chains of biconical cavities in the S2 cell wall layer. These cavities are helically orientated in the wood cell wall, following the microfibrillar arrangement in the S2 layer and best observed in the microscope under polarized light. Hale and Eaton (1985) have shown that the cavities are formed by the activities of lignolytic enzymes released from the hypha within the S2 layer by a process of 'start-stop' oscillatory growth of fine hyphae and subsequent widening around these hyphae to form the cavities (Leightly \& Eaton 1977).

While soft rot of wood under field conditions can be quite high 31.7 to $40.3 \%$ of beech and Scots pine test blocks over 54 weeks, losses under laboratory conditions on agar media can be as low 5.4\% (Eaton 1969, Mouzouras 1989). When weight losses caused by soft rot fungi and basidiomycetes are compared, the former do poorly: 17.4\% (Savoryella lignicola), with $73 \%$ weight loss by the basidiomycete Pycnoporus sanguineus (L.) Murrill (Bucher et al. 2004b). The latter has a much wider spectrum of lignolytic enzymes for the decay of wood (Pointing et al. 2000). Savoryella aquatica and S. lignicola have both been shown to cause soft rot of wood causing weight losses of 5.4-14.3-17.4 \% (Mouzouras 1989, Bucher et al. 2004a, b). 
Table 1 Genera referred to the Savoryellales

\begin{tabular}{lll}
\hline Genus & Current number & Species sequenced \\
& Species & \\
\hline Ascotaiwania & 13 & 7 \\
Canalisporium (sexual morph Ascothailandia) & 12 & 7 \\
Savoryella & 10 & 2 \\
Triadelphia & 18 & \\
\hline
\end{tabular}

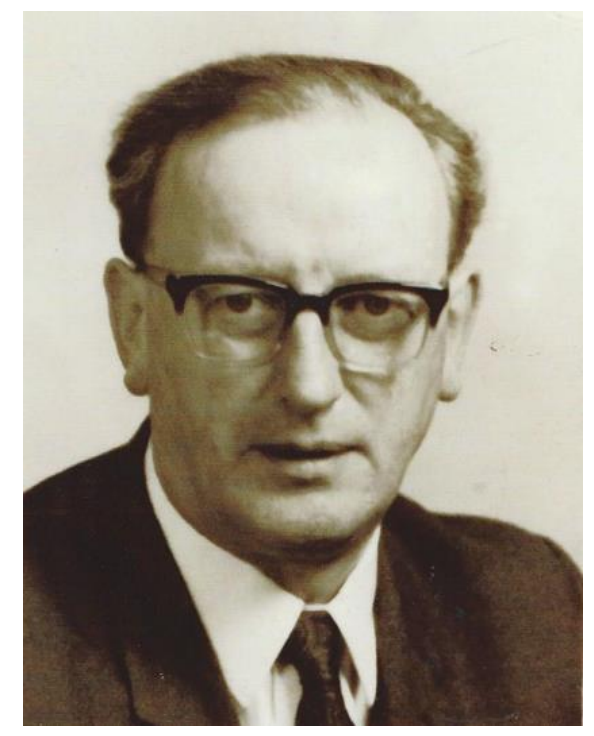

Fig. 6 - John Savory, a research scientist at the Forest Products Research Laboratory, Princes Risborough.

\section{John Savory}

This essay has been written to pay tribute to John Savory who devoted much of his research work on the characterization of soft rot decay in timber (Savory 1954a, b). He was pivotal in the introduction of the senior author to soft rot fungi, water cooling towers and experimental studies of these economically import group of fungi. Thus, the many studies on water cooling tower fungi that were initiated led to the discovery of the genus Savoryella, and named in his honour. John was a remarkable man, affable, good humored, a ready wit, a wonderful teacher and scientist. John Savory was not to know how widespread this genus was worldwide and its key position in the classification of the Ascomycota, as these developments took place after his death (Fig. 6).

\section{Conclusion}

The Savoryella story is a classic example of how the discovery of a single fungus can lead to such exciting results. This has led to the establishment of a well-supported order, which in turn has helped to resolve a whole range of genera, indeed families and orders. Many asexual genera, not previously classified, now find a home in well-established families/orders: Conioscypha (Conioscyphales), Carpoligna, Helicoön, Pleurothecium and Sterigmatobotrys (Pleurotheciales), Bactrodesmiastrum and Ascotaiwania persoonii (Bactrodesmiastrum clade) all having a relationship with the order Savoryellales (Canalisporium and Triadelphia) (Réblová \& Seifert 2004, Sri-indrasutdhi et al. 2010, Boonyuen et al. 2011, Réblová et al. 2012, Zelski et al. 2015, Hernandez-Restrepo et al. 2015, Réblová et al. 2016a).

The order Savoryellales was first thought to be a sister clade of the Coronophorales and Melanosporales (Boonyuen et al. 2011), but is now known to form a wider relationship with Conioscyphales, Pleurotheciales and Fuscosporales (Bactrodesmiastrum clade) with high statistical support (Réblová et al. 2016a, Yang et al. unpublished data). Therefore, the study of a little known aquatic ascomycete has resolved the taxonomy of a wide range of other taxa. 


\section{Acknowledgements}

We are grateful to the following who have contributed in different ways on various aspects of this project: Drs. Rod Eaton, Somsak Sivichai, Ka-Lai Pang, Veera Sri-indrasutdhi, Sue Read and Kevin Hyde. Gareth thanks Cynthia Savory for the photograph of John, for her hospitality and for many shared memories of a wonderful man.

\section{References}

Abdel-Wahab MA, Jones EBG. 2000 - Three new marine ascomycetes from driftwood in Australian sand dunes. Mycoscience 41, 87-96.

Baechler RH, Richards CA. 1961 - Deterioration of wood in cooling towers. Trans Am Soc MechEng 73, 1021-1025.

Baker DR. 1950 - Deterioration in cooling towers. Southern Power Ind. 65, 64-65.

Baker DR. 1951 - Wood deterioration in cooling towers. Petrol Eng 25, 76-80.

Baker DR. 1954 - Wooden cooling towers: decay is a major deterioration cause. Petrol Eng 26, 3744.

Boonyuen N, Chuaseeharonnachai C, Suetrong S, Sri-Indrasutdhi V, Sivichai S, Jones EBG, Pang KL. 2011 - Savoryellales (Hypocreomycetidae, Sordariomycetes): a novel lineage of aquatic

ascomycetes inferred from multiple-gene phylogenies of the genera Ascotaiwania, Ascothailandia and Savoryella. Mycologia 103, 1351-1350.

Borse BD., Tuwar AR., Patil VR, Patil S.Y, Borse KN 2016 - Aquatic ascomycetes from India: The genus Savoryella. Sci Park 3(28), 1-6.

Bucher VVC, Hyde KD, Pointing SB, Reddy CA. 2004a - Production of wood decay enzymes, mass loss and lignin solubilisation in wood by marine ascomycetes and their anamorphs. Fungal Divers 15, 1-14.

Bucher VVC, Pointing SB, Hyde KD, Reddy CA. 2004b - Production of wood enzyme, loss of mass, and lignin solubilisation in wood by diverse tropical freshwater fungi. Microb Ecol 48, 331-337.

Byrne PJ, Jones EBG. 1974 - Lignicolous marine fungi. Veroff Inst Meeresforschung, Bremerhaven Supplement 5, 301-320.

Crous PW, Gams W, Stalpers JA, Robert V, Stegehuis G. 2004 - MycoBank: an online initiative to launch mycology into the 21st century. Studies in Mycology 50, 19-22.

Duncan CG. 1960 - Soft rot in wood and toxicity studies of causal fungi. Am Wood Pres Ass Proc $56,27-37$.

Eaton RA. 1969 - The biodeterioration of timber in water-cooling towers. PhD thesis, Portsmouth Polytechnic, UK.

Eaton RA. 1972 - Fungi growing on wood in water cooling towers. Inter Biodeterioration Bull 8, 39-48.

Eaton RA, Jones EBG. 1970 - New fungi on timber from water-cooling towers. Nova Hedwigia 19: 779.

Eaton RA, Jones EBG. 1971a - The biodeterioration of timber in water-cooling towers. I. Fungal ecology and the decay of wood at Connah's Quay and Ince. Material and Organismen 6, 5180 .

Eaton RA, Jones EBG. 1971b - The biodeterioration of timber in water-cooling towers. II. Fungi growing on wood in different positions in a water cooling system. Material and Organismen $6,81-92$.

Eriksson OE, Hawksworth DL. 1986 - An alphabetical list of the generic names of ascomycetes. Syst Ascomycetum 5, 3-111.

Faces of Fungi database - 2016 http://www.facesoffungi.org (accessed 24 June 2016).

Findlay WPK, Savory JG. 1950 - Breakdown of timbers in water cooling-towers. Proc Inter Bot Congress (1950, Stockholm 7, 315-316. 
Hale MD, Eaton RA. 1985 - Oscillatory growth of fungal hyphae in wood cell walls. Trans $\mathrm{Br}$ mycol Soc 84, 277-288.

Hawksworth DL. 2011 - A new dawn for the naming of fungi: impacts of decisions made in Melbourne in July 2011 on the future publication and regulation of fungal names. IMA Fungus, 2(2), 155-62.

Hernández-Restrepo M, Gené J, Castañeda-Ruiz RF, Mena-Portales J, Guarro J. 2015 -Emendation of the genus Bactrodesmiastrum (Sordariomycetes) and description of Bactrodesmiastrum monilioides sp. nov. from plant debris in Spain. Mycological Progress 14(7), 48.

Index Fungorum - 2016 http://www.indexfungorum.org (accessed 24 June 2016).

Jaklitsch WM, Réblová M. 2015 - Savoryellaceae Jaklitsch \& Réblová. Index Fungorum 209: 1.

Jayasiri SC, Ariyawansa HA, Liu JK, Jones EBG, Hyde KD et al. 2015 - The Faces of Fungi database: Fungal names linked with morphology, molecular and human attributes. Fungal Divers 74, 3-18.

Jones AM, Jones EBG. 1993 - Observations on the marine gasteromycete Nia vibrissa. Mycol Res 97, 1-6.

Jones EBG. 1972 - The decay of timber in aquatic environments. Rec Ann Conv B.W.P.A. 31-49.

Jones EBG, Eaton RA. 1969 - Savoryella lignicola gen. et sp. nov. from water cooling towers. Trans Br mycol Soc 52, 161-174.

Jones EBG, Eaton RA, Somrithipol S. 2002 - Taeniolella rudis and Taeniolella longissima sp. nov. with secondary sympodioconidia from freshwater habitats. Mycoscience 43, 201-206.

Jones EBG, Hyde KD. 1992 - Taxonomic studies on Savoryella Jones et Eaton (Ascomycotina). Bot Mar 35, 83-91.

Jones EBG, Stewart RJ. 1972 - Tricladium varium, an aquatic hyphomycete on wood in watercooling towers. Trans Br mycol Soc 59, 163-167.

Jones EBG, Suetrong S, Sakayaroj J, Bahkali AH, Abdel-Wahab MA, Boekhout T, Pang, KL. 2015 -Classification of marine Ascomycota, Basidiomycota, Blastocladiomycota and Chytridiomycota. Fungal Diversity, 73, 1-72.

Kohlmeyer J, Kohlmeyer E. 1979 - Marine mycology: the higher fungi. New York: Academic Press. p 1-690.

Leightly LE. 1980 - Further studies on soft rot decay of CCA treated Eucalyptus power transmission poles in Queensland, Australia. Inter Res Group Wood Preser Doc IRGH/WP/1115: 1-17.

Leightly LE, Eaton RA. 1977 - Mechanisms of decay of timber by aquatic micro-organisms. Brit Wood Preserv Assoc., Convention Record 1-26.

Maharachchikumbura SSN, Hyde KD, Jones EBG, McKenzie EHC, Huang SK, Abdel-Wahab MA, Daranagama DA, Dayarathne M, 1D’Souyza KJ, Goonasekara ID, Hongsanan S, Jayawardena RS, Kirk, PM, Konta RH, Liu JK, Norphanphoun C, Pang KL, Perera RH, Senanayake IC, Shang Q, Shenoy BD, Xiao Y, Bahkali AH, Kang J, Somrithipol S, Suetrong S. 2015 - Towards a natural classification and backbone tree for Sordariomycetes. Fungal Divers 72(2), 199-301.

Maharachchikumbura SSN, Hyde KD, Jones EGB, McKenzie EHC, Bhat JD, Dayarathne MC, Huang SK, Norphanphoun C, Senanayake IC, Perera RH, Shang QJ, Xiao Y, D'souza MJ, Hongsanan S, Jayawardena RS, Daranagama DA, Konta S, Goonasekara ID, Zhuang WY, Jeewon R, Phillips AJL, Abdel-Wahab MA, Al-Sadi AM, Bahkali AH, Boonmee S, Boonyuen N, Cheewangkoon R, Dissanayake AJ, Kang J, Li QR, Liu JK, Liu ZY, Luangsaard JJ, Pang KL, Phookamsak R, Promputtha I, Suetrong S, Wen T, Wijayawardene NN. 2016 - Families of Sordariomycetes. Fungal Diversity 79, 1-317.

Mouzouras R. 1986 - Soft rot decay of wood by marine microfungi. J Inst Wood Sci (1989) 11, 193-201.

Mouzouras R. 1989 - Decay of mangrove wood by marine fungi. Bot Mar 32, 65-69.

Natarajan K, Udaiyan K. 1978 - Cooling towers fungi in India. Inter Biodet Bull 14, 85-87. 
Nawawi A, Kuthubutheen AJ. 1989 - Canalisporium, a new genus of lignicolous hyphomycetes from Malaysia. Mycotaxon. 34(2), 475-487.

NCBI - 2016 http://www.ncbi.nlm.nih.gov/nuccore org (accessed 24 June 2016).

Pointing SB, Jones EBG, Vrijmoed LLP. 2000 - Optimization of laccase production by Pycnoporus sanguineus in submerged liquid culture. Mycologia 92, 139-144.

Read SJ, Jones EBG, Moss ST. 1993 - Taxonomic studies of marine Ascomycotina: ultrastructure of the asci, ascospores and appendages of Savoryella species. Can J Bot 71, 273-283.

Réblová M, Miller AN, Rossman AY, Seifert KA, Crous PW, Hawksworth DL, Abdel-Wahab MA, Cannon PF, Daranagama DA, De Beer ZW, Huang S-K, Hyde KD, Jayawardena R, Jaklitsch W, Jones EBG, Ju Y-M, Judith C, Maharachchikumbura SSN, Pang KL, Petrini LE, Raja HA, Romero AI, Shearer C, Senanayake IC, Voglmayr H, Weir BS, Wijayawardene NN. 2016b - Recommendations for competing sexual-asexually typified generic names in Sordariomycetes (except Diaporthales, Hypocreales, and Magnaporthales). IMA Fungus 7(1), 131-153.

Réblová M, Seifert KA. 2004 - Conioscyphascus, a new ascomycetous genus for holomorphs with Conioscypha anamorphs. Stud Mycol 50(1), 95-108.

Réblová M, Seifert KA, Fournier J, Štěpánek V. 2012 - Phylogenetic classification of Pleurothecium and Pleurotheciella gen. nov. and its Dactylaria-like anamorph (Sordariomycetes) based on nuclear ribosomal and protein-coding genes. Mycologia 104(6), 1299-314.

Réblová M, Seifert KA, Fournier J, Štěpánek VB 2016a - Newly recognised lineages of perithecial ascomycetes: the new orders Conioscyphales and Pleurotheciales. Persoonia 37, 57-81.

Savory JG. 1954a - Breakdown of timber by Ascomycetes and Fungi Imperfecti. Ann Appl Biol 41, 336-347.

Savory JG. 1954b - Damage to wood caused by micro-organisms. J Appl Bact 17, 213-218.

Sri-indrasutdhi V, Boonyuen N, Sivichai S, Jones EBG 2010 - Wood inhabiting freshwater fungi from Thailand: Ascothailandia gen. et sp. nov., Canalisporium grenadoidia sp. nov. with a key to Canalisporium species (Sordariomycetes Ascomycota). Mycoscience. 51(6), 411420.

Taylor JW. 2011 - One Fungus. One Name: DNA and fungal nomenclature twenty years after PCR. IMA Fungus 2(2), 113-120.

Udaiyan K, Manian S. 1991a - Fungal deteriogens from treated timber packing of water cooling towers. Inter Biodet 27, 275-279.

Udaiyan K, Manian S. 1991b - Fungi colonising wood in the cooling towers water system at the Madras fertilizer company, Madras, India. Inter Biodet 27, 351-371.

Vijaykrishna D, Jeewon R, Hyde KD. 2006 - Molecular taxonomy, origins and evolution of freshwater ascomycetes. Fungal Divers 23, 351-390.

Zelski SE, Raja HA, Miller AN, Shearer CA. 2015 - Conioscypha peruviana sp. nov., its phylogenetic placement based on 28S rRNA gene, and a report of Conioscypha gracilis comb. nov. from Peru. Mycoscience 56(3), 319-325. 